\title{
Sprawozdanie z VI Ogólnopolskiej Konferencji Naukowej z zakresu edukacji globalnej pt. „Migracje w dobie pandemii. Wyzwania dla idei i praktyki edukacji globalnej". Warszawa, 25 maja 2021 roku
}

Po raz szósty odbyła się w Instytucie Pedagogiki (Wydział Nauk Pedagogicznych) Uniwersytetu Kardynała Stefana Wyszyńskiego w Warszawie (UKSW) we współpracy z Wydziałem Studiów nad Rodziną UKSW, konferencja z zakresu edukacji globalnej. Odbyła się ona w formie zdalnej na platformie Cisco Webex. W tym roku jej tytuł brzmiał: „Migracje w dobie pandemii. Wyzwania dla idei i praktyki edukacji globalnej". Konferencja została objęta patronatem naukowym Komitetu Nauk Pedagogicznych Polskiej Akademii Nauk. W spotkaniu 25 maja 2021 roku wzięło udział 23 prelegentów reprezentujących dziesięć ośrodków akademickich krajowych i jeden zagraniczny, ponadto przedstawiciele trzech organizacji pozarządowych działających na rzecz migrantów oraz dwóch nauczycieli szkół podstawowych.

Obrady zostały podzielone na cztery sesje: jedną sesję plenarną i trzy grupy tematyczne oraz metodyczny warsztat dla uczestników konferencji. W imieniu organizatorów uczestników spotkania przywitał przewodniczący komitetu organizacyjnego - dr hab. Zbigniew Babicki prof. uczelni. Uroczystego otwarcia konferencji dokonał prof. dr hab. Jarosław Michalski, dyrektor Instytutu Pedagogiki UKSW. J. Michalski witając zebranych gości zwrócił uwagę na aktualność problematyki migracji w kontekście pandemii, która jest wyzwaniem zarówno dla teorii, jak i praktyki. W imieniu gospodarzy dyrektor życzył wszystkim zebranym owocnych obrad. Następnie głos zabrał ks. biskup dr Krzysztof Zadarko, przewodniczący Rady Komisji Episkopatu Polski ds. Migracji, Turystyki i Pielgrzymek, podkreślając stanowisko Kościoła katolickiego wobec problematyki migracyjnej.

Sesję plenarną poprowadził Z. Babicki, który przekazał głos prof. dr hab. Jerzemu Nikitorowiczowi z Uniwersytetu w Białymstoku. J. Nikitorowicz wygłosił wykład wprowadzający w problematykę konferencji nt. Ku zrównoważonemu modelowi tożsamości wobec /w kontekście/ ustawicznych migracji. W swoim wystąpieniu

\footnotetext{
* Ks. dr hab. Zbigniew Babicki, prof. uczelni, Uniwersytet Kardynała Stefana Wyszyńskiego w Warszawie, Wydział Nauk Pedagogicznych; e-mail: z.babicki@uksw.edu.pl.
} 
prelegent przedstawił propozycję zrównoważonego modelu tożsamości, który wydaje się odpowiadać na potrzeby świata, w którym ruchy migracyjne mają charakter powszechny. Opowiedział się przeciwko dążeniom asymilacyjnym. Wskazał na znaczenie zintegrowanego rozwoju tożsamości również w kontekście powszechnych migracji. Rozwój tożsamości zintegrowanej jest możliwy w oparciu o rdzeń tożsamościowy, tożsamość dziedziczoną. W działaniach edukacyjnych niezbędne jest uwzględnienie tego rdzenia i przejście od nastawienia na asymilację ku integracji, dla której dobrą przestrzenią jest szkoła. Jako drugi wystąpił dr hab. Janusz Balicki prof. uczelni z Uniwersytetu Kardynała Stefana Wyszyńskiego w Warszawie. Temat jego wystąpienia brzmiał: Wyzwania globalnej edukacji w Polsce w kontekście procesów demograficznych i migracyjnych w Europie i Afryce. Mówca w swoim wystąpieniu nakreślił wyzwania jakie stawiają przed edukacją globalną w Polsce teraźniejsze i przyszłe procesy demograficzne i migracyjne w świecie, a w szczególności zachodzące na dwóch bliskich geograficznie kontynentach wymienionych w tytule. Stwierdził, że w Europie mamy do uczynnienia ze zjawiskiem niskiej dzietności i starzeniem się społeczeństwa, a w Afryce z wysoką dzietnością, nieporównywalnie $\mathrm{z}$ innymi kontynentami młodą populacją i wysokim procentem ludzi myślących o emigracji. Jako następna zabrała głos dr hab. Aneta Rogalska-Marasińska prof. uczelni z Uniwersytetu Łódzkiego. Temat jej wystąpienia brzmiał: Covid -19 jako „zmienna niezależna” międzykulturowego poznania. Prelegentka skoncentrowała uwagę słuchaczy na przedstawieniu pozytywnych zmian, płynących z globalnego „wstrząsu” społecznego, jakim stała się pandemia Covid-19. W trzech punktach ukazała wpływ Covid-19 na wzajemne poznanie. Pierwszy dotyczył edukacji międzykulturowej w perspektywie geograficznej. Drugi nawiązywał do obszaru komparatystyki pedagogicznej, porównując funkcjonowanie systemów edukacyjnych w „reżimie sanitarnym”. Trzeci najsilniej odwoływał się do aspektu wychowawczego i kształtowania postaw, wynikających z wyzwań humanitarnych oraz potrzeb wpisujących się w zadania edukacji globalnej.

Po tym referacie moderator zaprosił wszystkich uczestników do dyskusji, w której powrócono do zagadnień poruszanych w wystąpieniach, aby je pogłębić. Po dyskusji została zarządzona przerwa. Po przerwie rozpoczęły się obrady sesji I, której moderatorem była dr Katarzyna Stankiewicz z UKSW. Zaprezentowano w niej cztery referaty. Jako pierwszy zabrał głos dr hab. Józef Młyński prof. uczelni, reprezentujący Uniwersytet Pedagogiczny im. KEN w Krakowie. Temat jego wystąpienia brzmiał: Praca socjalna (bezpieczeństwo socjalne) $z$ migrantami $w$ środowisku lokalnym jako wyzwanie dla polityki społecznej. W swoim wystąpieniu ukazał on działania pracowników socjalnych w obszarze bezpieczeństwa socjalnego realizowanych na rzecz migrantów w czasie trudnej sytuacji pandemii Covid-19. Kolejnymi mówczyniami były dr Katarzyna Stankiewicz z UKSW i dr hab. Anna Żurek z Uniwersytetu Wrocławskiego. Przedstawiły one temat: Wsparcie uczniów cudzoziemskich podczas edukacji zdalnej $w$ dobie pandemii. Perspektywa wolontariusza. Prelegentki podkreślały, że kryzys związany z pandemią COVID-19 miał 
zdecydowanie większy wpływ na imigrantów i ich rodziny niż na inne grupy społeczne. Przedstawiły zakres wsparcia uczniów cudzoziemskich podczas edukacji zdalnej w dobie pandemii z perspektywy wolontariusza organizacji trzeciego sektora lub studenta odbywającego praktyki. Zdaniem wolontariuszy uczniowie cudzoziemscy w dobie pandemii potrzebują dodatkowego wsparcia ze strony nauczycieli, innych specjalistów (pedagoga, psychologa), ale też wolontariusza i po prostu polskiego rówieśnika. W dalszej kolejności wystąpił dr Jerzy Kowalewski z Fundacji na Rzecz Dwujęzyczności Edunowa. Temat jego wystąpienia brzmiał: Perspektywy edukacji kulturowej $w$ dobie migracji i nauczania zdalnego. Przykład Ukrainy. Prelegent prezentował swoje poglądy i doświadczenia w obszarze idei edukacji kulturowej; koncepcji nauczania według wartości; kształcenia i wychowania, które mają przygotowywać do rozwiązywania problemów migracyjnych. Zaprezentował także współczesne problemy związane z nauczaniem (prezentacją kultury polskiej zagranicą: zmiany kulturowe w Polsce, globalizacja kultury). Następnie głos zabrała dr Barbara Głasek z UKSW, która przedstawiła referat zatytułowany: Problemy integracji dzieci cudzoziemskich w polskich przedszkolach $w$ świetle opinii dyrekcji i nauczycieli placówek warszawskich. Jej zdaniem w dobie globalizacji wiele osób poszukuje pracy i lepszego życia w innych częściach świata. Często wyjeżdżają oni wraz z rodzinami. Dzieci zgodnie z przepisami obowiązującymi w wielu krajach mają zapewniony dostęp do edukacji. Podobnie w Polsce dzieci cudzoziemców mogą bezpłatnie kształcić się w publicznych szkołach i przedszkolach. Napotykają one jednak na liczne bariery.

Po tym wystąpieniu, które było ostatnim w I sesji prowadząca obrady zaprosiła do dyskusji i wymiany poglądów. Po dyskusji została zarządzona przerwa. Po przerwie rozpoczęły się obrady sesji II, której moderatorem był Z. Babicki. Prowadzący w pierwszej kolejności udzielił głosu sobie, aby wygłosić referat pt. Problem migracji a przyjaźń społeczna i zadania edukacji. Prelegent przekonywał, że w dobie poszerzających się społeczeństw wielokulturowych istnieje potrzeba budowania nowego ładu społecznego opartego na przyjaźni społecznej. Głównym punktem odniesienia dla tych rozważań stała się w encyklika papieża Franciszka Fratelli tutti, która mówi o braterstwie i przyjaźni społecznej. W rozumieniu papieża najwłaściwszą drogą do budowania nowego ładu społecznego opartego na przyjaźni społecznej i otwartości jest gruntowna edukacja, która będzie kształtować postawy dobra wspólnego i budować wspólnotę międzyludzką odwołującą się do wzajemnej solidarności.

Jako kolejny zabrał głos dr Tadeusz Piątek z Politechniki Rzeszowskiej im. Ignacego Łukasiewicza, który zaprezentował referat pt. Model wykształconego człowieka komponent edukacji globalnej. Prelegent zwrócił uwagę, że stworzenie modelu wykształconego człowieka doby szeroko rozumianej globalizacji to określenie kompetencji jakie będzie posiadał człowiek współcześnie funkcjonujący w obszarze całego globu. Funkcjonowanie to jest efektem m.in.: rozwoju technologii informacyjno-komunikacyjnych, postępu cywilizacyjnego, stałego trendu poszukiwania 
lepiej płatnej pracy (migracja i emigracja), różnego poziomu bezpieczeństwa czy też zagrożenia życia (uchodźctwo). W dalszej kolejności głos zabrały dr Magdalena Kuleta-Hulboj i mgr Dobrawa Aleksiak z Uniwersytetu Warszawskiego, które wygłosiły referat pt. „Czego Jaś się nie nauczy...”, czyli krytyczna analiza obecności edukacji globalnej w podstawie programowej. W swoim referacie zaprezentowały najważniejsze wyniki badania zrealizowanego w 2020 r., którego celem była diagnoza obecności edukacji globalnej w "nowej” podstawie programowej (2017 r.) oraz rekonstrukcja sposobów jej ujmowania w tym dokumencie. Badaczki dążyły do zdobycia odpowiedzi na dwa pytania: (1) czy edukacja globalna jest obecna w podstawie programowej kształcenia ogólnego w szkołach podstawowych w obszarze trzech przedmiotów (historii, wiedzy o społeczeństwie i geografii)?; (2) w ramach jakich schematów interpretacyjnych jest ujmowana? Jako ostatnia w tej sesji zabrała głos dr Alicja Joanna Siegień-Matyjewicz reprezentująca Uniwersytet WarmińskoMazurski w Olsztynie. Tytuł jej wystąpienia brzmiał: Edukacja międzykulturowa w zglobalizowanym świecie i jej miejsce w polskim systemie nauczania w opinii nauczycieli szkół podstawowych. W swoim referacie poruszyła ona kwestie dotyczące współczesnych wyzwań edukacji międzykulturowej. Przedstawiła specyfikę pracy nauczyciela w środowisku zróżnicowanym pod względem kulturowym. Następnie zaprezentowała część wyników badań przeprowadzonych wśród nauczycieli szkół podstawowych w Olsztynie, które miały na celu poznanie ich opinii na temat edukacji międzykulturowej w dzisiejszym zglobalizowanym świecie i jej miejsca w polskim systemie nauczania.

Po tym wystąpieniu, które było ostatnim w II sesji prowadzący obrady zaprosił do dyskusji i wymiany poglądów. Po dyskusji została zarządzona przerwa. Po przerwie rozpoczęły się obrady sesji III, której moderatorem był dr hab. Dariusz Stępkowski, prof. uczelni (UKSW). Pierwszy zabrał głos prof. Isaias Rivera reprezentujący Corvinus University of Budapest, który wygłosił referat pt. The Evolution of Education during the times of Pandemic and its Future: Progressive Education. Prelegent odniósł się do ogólnoświatowych trendów globalizacyjnych i podkreślił znaczenie dostępu do najnowszych technologii na proces kształcenia. Zwrócił szczególną uwagę na wpływ zróżnicowania ekonomicznego pomiędzy krajami Ameryki Północnej i Europy a możliwościami dostępu do wiedzy i szansy na naukę. Następnie przemówił dr Mateusz Marciniak z Uniwersytetu im. Adama Mickiewicza w Poznaniu. Tytuł jego wystąpienia brzmiał: Instytucjonalne uwarunkowania partycypacji młodzieży akademickiej $w$ międzynarodowej wymianie studenckiej. Prelegent podkreślił, że mobilność młodzieży akademickiej jest zjawiskiem wymagającym uwzględnienia w analizie cech grupy jaką są osoby studiujące oraz kontekstu studiowania wyznaczanego przez sytuację krajową i międzynarodową. Liczne badania nad uwarunkowaniami (barierami i motywami) mobilności studenckiej wskazują, że jakość kształcenia uczelni zagranicznych oraz uznawalność efektów nauczania na niej nie zajmują kluczowego miejsca wśród czynników uwzględnianych w podejmowaniu decyzji o wyjeździe. Jako kolejna zabrała głos 
mgr Ariadna Ciążela reprezentująca Akademię Pedagogiki Specjalnej im. Marii Grzegorzewskiej w Warszawie. Wygłosiła ona referat pt. Nieformalna edukacja obywatelska poprzez kampanie społeczne i media społecznościowe. Mówczyni odwołując się do wyników badań własnych wykazała, że głównym źródłem wiedzy studentów na temat ochrony środowiska są media społecznościowe. Okazuje się bowiem, że media społecznościowe stały się miejscem zarówno edukacji nieformalnej i kształtowania pożądanych postaw obywatelskich, jak i wyrażania własnych poglądów oraz solidarności z grupami i ruchami społecznymi.

Po tym wystąpieniu, które było ostatnim w III sesji prowadzący obrady zaprosił do dyskusji i wymiany poglądów. Po dyskusji została zarządzona przerwa. Po przerwie rozpoczęły się obrady sesji IV, której moderatorami były dr Aleksandra KulpaPuczyńska UKSW i dr Katarzyna Stankiewicz UKSW. Sesja ta została poświęcona praktykom, w której wystąpiło sześć prelegentek reprezentujące różne instytucje. Porządek wystąpień był następujący: Elżbieta Kielak, Anna Huminiak (Fundacja Rozwoju Systemu Edukacji i Polsko-Niemiecka Współpraca Młodzieży). Temat wystąpienia: Warsztaty Edukacji Międzykulturowej metodami edukacji pozaformalnej on-line. Agnieszka Kosowicz (Fundacja Polskie Forum Migracyjne). Temat wystąpienia: Wsparcie rodzin migranckich i uchodźczych podczas pandemii: wsparcie edukacyjne, psychologiczne, prawne i integracyjne. Khedi Alieva (Fundacja Kobiety Wędrowne). Temat wystąpienia: Aktywność społeczna uchodźczyń w sytuacji pandemii - działania Fundacji Kobiety Wędrowne. Nina Markiewicz-Sobieraj (Szkoła Podstawowa $\mathrm{nr} 16 \mathrm{w}$ Gdańsku). Temat wystąpienia: Praca $z$ dziećmi $z$ doświadczeniem migracyjnym podczas pandemii - przykład Gdańska. Nataliya Basko (Szkoła Podstawowa nr 355 w Warszawie). Temat wystąpienia: Pandemia a edukacja dzieci $z$ doświadczeniem migracyjnym. Doświadczenie psychologa praktyka.

Podczas konferencji uczestników, w tym studentów UKSW, zaproszono do udziału w Warsztacie edukacji międzykulturowej i globalnej w ramach projektu Warsztaty Edukacji Międzykulturowej „Między Innymi”, realizowanego wspólnie przez Fundację Rozwoju Systemu Edukacji oraz Polsko-Niemiecką Współpracę Młodzieży, który poprowadziły Elżbieta Kielak i Anna Huminiak. W warsztacie wykorzystano metody edukacji pozaformalnej. Pozwoliły one zagłębić się w temat międzykulturowości w kontekście migracji. Doświadczenia z powyższego warsztatu zostały też zaprezentowane podczas sesji IV konferencji.

Na zakończenie konferencji Z. Babicki w imieniu organizatorów podziękował wszystkim uczestnikom za udział w tym naukowym wydarzeniu i zaprosił do udziału w przyszłorocznej konferencji. 